\title{
Analisis Pembacaan dan Penulisan Data Buku Menggunakan RFID Mifare RC-522 untuk Perpustakaan
}

\author{
Mochamad Reza Adhitama ${ }^{1}$, Gede Eka Wiantara Putra ${ }^{2}$ \\ ${ }^{1}$ ITB STIKOM Bali Kampus Jimbaran, ${ }^{2}$ Politeknik Nasional Denpasar \\ e-mail: 1ac.mra.it@gmail.com, ${ }^{2}$ videline@yahoo.com \\ Diajukan: 9 Mei 2019; Direvisi: 6 November 2019; Diterima: 7 November 2019
}

\begin{abstract}
Abstrak
Perpustakaan modern memerlukan suatu sistem untuk mengidentifikasi buku satu dengan yang lain. Saat ini sistem automasi perpustakaan sudah menerapkan sistem identifikasi menggunakan barcode. Namun teknologi ini memerlukan kontak langsung atau terlihat agar dapat dibaca oleh sistem. Teknologi alternatif yang dapat digunakan adalah RFID. Kelebihan RFID adalah tidak memerlukan kontak langsung (contactless) dengan tingkat error yang rendah dan data yang dapat ditulis berulang kali. Metode penelitian yang digunakan adalah waterfall. Komponen yang digunakan pada sistem ini adalah RFID Tag/Transponder (Mifare Classic 1K), RFID Interrogator Module (Mifare RC-522) yang dirangkaikan dengan Arduino Uno R3 yang terhubung dengan komputer. Pada hasil pengujian didapatkan bahwa sistem ini dapat melakukan pembacaan data pada tag dengan rekomendasi jarak baca di bawah $3.5 \mathrm{~cm}$ (memiliki tingkat akurasi di atas 80\%) dan penulisan data pada tag dengan rekomendasi jarak tulis di bawah $2.5 \mathrm{~cm}$ (memiliki tingkat akurasi di atas 80\%).
\end{abstract}

Kata kunci: RFID, Perpustakaan, Identifikasi Objek, Sistem Automasi Perpustakaan.

\begin{abstract}
The modern library requires a system to identify books with one and another. Currently, library automation systems have implemented identification systems using barcodes. But this technology requires direct contact or line of sight by the system to able to read it. An alternative technology that can be used is RFID. The advantage of RFID is that it does not require direct contact (contactless) with a low reading error rate and data that can be written repeatedly. The research method used is the waterfall. The components used in this system are RFID Tag/Transponder (Mifare Classic 1K), RFID Interrogator Module (Mifare RC-522) which is coupled with the Arduino Uno R3 which is connected to a computer. In the test results, it was found that this system can read data on tags with recommendations for reading distance below $3.5 \mathrm{~cm}$ (having an accuracy level above 80\%) and writing data on tags with recommendations for write distance below $2.5 \mathrm{~cm}$ (having an accuracy rate above $80 \%$ ).
\end{abstract}

Keywords: RFID, Library, Object Identification, Library Automation System.

\section{Pendahuluan}

Perpustakaan merupakan salah satu tempat yang memiliki peranan yang penting sebagai wadah informasi dalam berbagai bidang ilmu pengetahuan dan teknologi. Dengan banyaknya koleksi yang dikelola perpustakaan, tentu perpustakaan memerlukan tenaga ahli yang diperbantukan dengan penerapan teknologi. Saat ini, banyak perpustakaan telah menerapkan teknologi sistem automasi perpustakaan. Hal ini didukung dengan maraknya sistem automasi perpustakaan yang bersifat open-source. Berdasarkan pada [1], [2] , sistem automasi perpustakaan mempermudah pelayanan administrasi pada perpustakaan. Namun sistem ini dirasa belum cukup apabila tidak dibantu dengan teknologi yang dapat dengan mudah mengidentifikasi koleksi satu dengan lainnya.

Selama ini, sistem automasi perpustakaan telah menerapkan barcode sebagai bentuk identifikasi koleksi satu dengan lainnya [2], [3]. Namun barcode memiliki beberapa kelemahan, di antaranya membutuhkan line of sight dan kerentanan terhadap daya tahan penyimpanan [4]. Teknologi alternatif yang dapat diterapkan adalah RFID. Berdasarkan komparasi antara RFID dan barcode, RFID memiliki banyak keunggulan saat diterapkan pada perpustakaan [4]. Di antaranya contactless, tingkat error pembacaan yang sangat rendah [5] dan pembacaan yang sangat cepat ( $\sim \mathrm{ms}$ ) [4]. Dengan kelebihan tersebut, RFID merupakan pengembangan teknologi identifikasi objek yang lebih baik dari pada barcode [4]. Untuk 
memanajemen penerapan RFID, dibutuhkan alat RFID interogator [5]. Alat ini berfungsi untuk menuliskan data detail buku ke dalam tag dan membaca data yang ada pada tag.

Pada penelitian ini dibuat sebuah analisis terhadap pembacaan dan penulisan data buku dalam sistem RFID. Metode penelitian yang digunakan adalah waterfall. [6]. Sistem terdiri dari transponder (tag) Mifare Classic 1K [7], modul RFID interrogator Mifare RC522 [8] yang dirangkaikan dengan Arduino Uno R3 [9] menggunakan koneksi serial untuk komunikasi dengan host computer. Host computer berfungsi untuk mengatur tampilan komunikasi tag dan interogator. Di mana pada mode writer, tiap-tiap tag akan di tulis data buku sebelum ditempelkan pada buku dan pada mode reader, aplikasi dapat menampilkan data yang ada pada tag yang sudah dituliskan data sebelumnya.

\section{Metode Penelitian}

Pada penelitian ini digunakan metode penelitian waterfall [6]. Pada bagian Requirement and analisys, dilakukan pengumpulan data terkait dengan sistem identifikasi buku berbasis RFID pada perpustakaan dan kebutuhan sistem yang akan dibangun. Pada System and software design, dilakukan perancangan sistem pembacaan dan penulisan data dari komputer-host ke RFID Tag melalui RFID Interogator. Pada Implementation and unit testing, dilakukan implementasi dari sistem RFID yang dibangun. Terakhir pada Integration and system testing, dilakukan pengujian terhadap pembacaan dan penulisan data dari RFID tag.

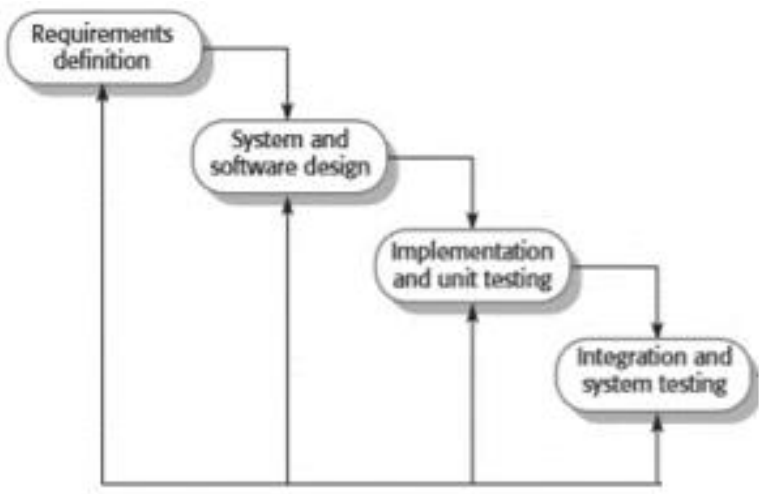

Gambar 1. Model Waterfall menurut Sommervile [6].

2.1. Perancangan Sistem RFID

\subsubsection{Mifare-RC522}
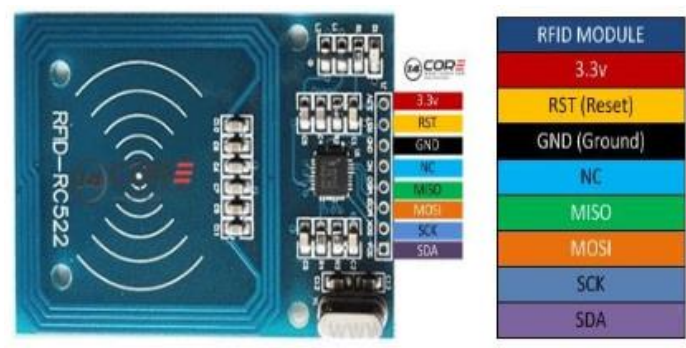

Gambar 2. Mifare-RC522 [10].

Mifare RC-522 (Gambar 2.) merupakan modul RFID interogator yang bekerja pada frekuensi 13.56 MHz. RC522 mendukung mode ISO 14443A/MIFARE. Modul ini menggunkan SPI untuk berkomunikasi dengan mikrokontroller [8], [10].

Spesifikasi RC522 - RFID Interogator:

- Operating Current :13-26mA/DC 3.3V.

- Idle Current :10-13mA/DC 3.3V.

- Sleep Current: < 80uA and Peak Current: < 30mA.

- Operating Frequency: 13.56MHz. 
- Supported card types: mifare1 S50, mifarel S70, MIFARE Ultralight, mifare Pro, MIFARE DESFire.

- Environmental Operating Temperature: -20 - 80 degrees Celsius.

- Environmental Storage Temperature: $-40-85$ degrees Celsius.

- Relative humidity: relative humidity 5\% -95\%.

- Reader Distance: $\geq 50 \mathrm{~mm} / 1.95 "$ (mifare 1).

- Module Size: $40 \mathrm{~mm} \times 60 \mathrm{~mm}$.

- Module interface: SPI.

- Data transfer rate: Maximum 10Mbit/s.

\subsubsection{Tag Mifare 1K Classic}

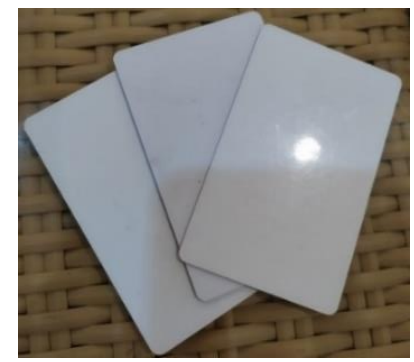

Gambar 3. Tag Mifare Classic 1K.

Dikembangkan oleh NXP Semiconductors, Mifare Classic EV1 (Gambar 3.) merupakan contactless smart card berbasis ISO/IEC 14443 Type A. Mifare Classic EV1 yang digunakan adalah dengan memori $1 \mathrm{~K}$. Fitur dan keunggulan [7] :

- Transmisi data dan suplai energi contactless.

- Jarak pengoperasian mencapai $100 \mathrm{~mm}$, tergantung dari geometri antena dan konfigurasi reader.

- Bekerja pada frekuensi $13.56 \mathrm{MHz}$.

- Transfer data $106 \mathrm{kbit} / \mathrm{s}$.

- Data integrity of 16-bit CRC, parity, bit coding, bit counting.

- Anticollision.

- Tipikal waktu transaksi tiket $<100 \mathrm{~ms}$ (termasuk backup management).

- 7 Byte UID atau 4 Byte NUID.

- Mendukung Random ID (7 Byte UID version).

\subsubsection{Arduino Uno R3}

Arduino Uno merupakan mikrokontroler berbasis ATmega328p. Memiliki 14 digital pin (di mana 6 pin dengan tanda “ " dapat digunakan sebagai PWM), 6 analog input, sebuah $16 \mathrm{MHz}$ quartz crystal, koneksi USB, power jack, sebuah ICSP header, dan reset button [9]. Spesifikasi Arduino Uno dapat dilihat pada Tabel 1.

Tabel 1. Spesifikasi Arduino Uno [9].

\begin{tabular}{ll}
\hline Operating Voltage & $5 \mathrm{~V}$ \\
\hline Input Voltage (recommended) & $7-12 \mathrm{~V}$ \\
\hline Input Voltage (limit) & $6-20 \mathrm{~V}$ \\
\hline Digital I/O Pins & 14 (of wich 6 provide PWM output) \\
\hline PWM Digital I/O Pins & 6 \\
\hline Analog Input Pins & 6 \\
\hline DC Current per I/O Pins & $20 \mathrm{~mA}$ \\
\hline DC Current for 3.3V pin & $50 \mathrm{~mA}$ \\
\hline Flash Memory & $32 \mathrm{~KB}(\mathrm{ATmega328 \textrm {P }})$ of wich $0.5 \mathrm{~KB}$ used by bootloader \\
\hline SRAM & $2 \mathrm{~KB}(\mathrm{ATmega328 \textrm {P } )}$ \\
\hline EEPROM & $1 \mathrm{~KB}(\mathrm{ATmega328 \textrm {P }}$ \\
\hline Clock Speed & $16 \mathrm{Mhz}$ \\
\hline LED_BUILTIN & 13 \\
\hline Length & $68.6 \mathrm{~mm}$ \\
\hline Width & $53.4 \mathrm{~mm}$ \\
\hline Weigth & $25 \mathrm{~g}$ \\
\hline
\end{tabular}

Analisis Pembacaan dan Penulisan Data Buku Menggunakan RFID Mifare RC-522 untuk Perpustakaan (Mochamad Reza Adhitama) 


\subsubsection{Computer Host}

Komputer berfungsi sebagai pengatur alur informasi dari tag yang terdeteksi oleh sistem RFID dan mengatur komunikasi antara tag dan interogator. Host berupa komputer yang terhubung dengan sistem RFID menggunakan komunikasi serial.

\subsection{Perancangan Perangkat Keras (Hardware)}

Gambar 4 merupakan block diagram dari sistem identifikasi buku berbasis RFID untuk perpustakaan. Sistem yang dibangun menggunakan Mifare-RC522 dan Arduino Uno R3 yang terhubung dengan komputer menggunakan komunikasi serial port. Tag yang terjadi akan diproses sesuai dengan program yang di pilih (menulis data atau membaca data RFID Tag).

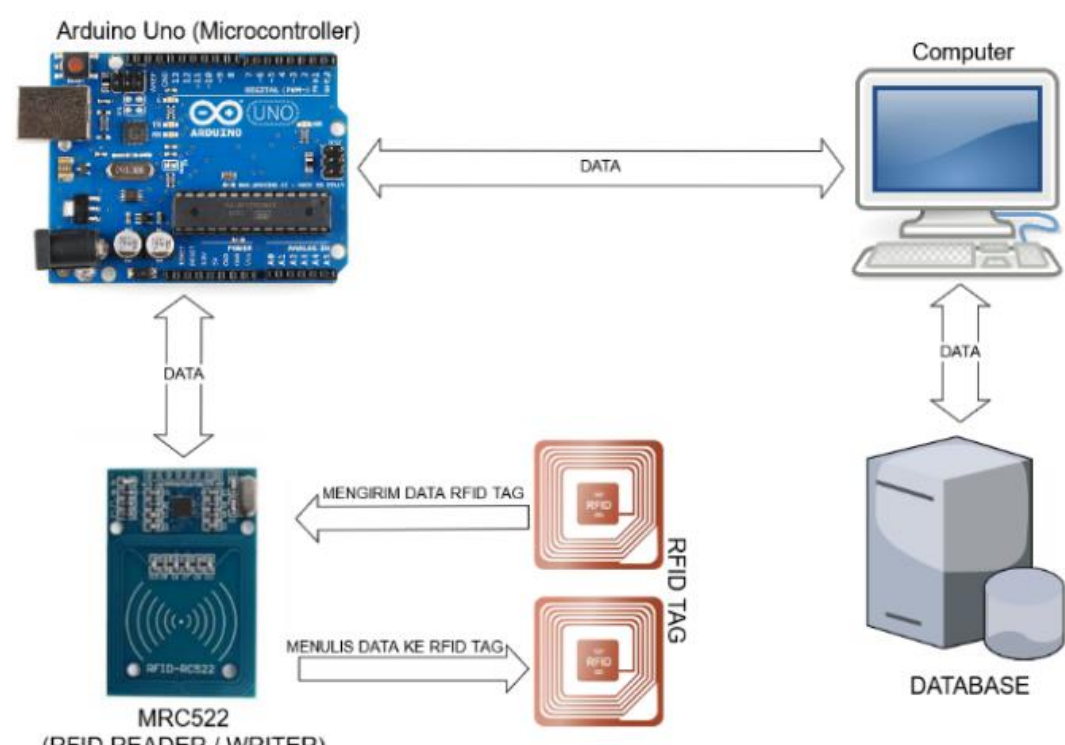

Gambar 4. Block diagram.

Gambar 5 merupakan wiring diagram dari RFID interogator (Arduino Uno dengan MRC522). Pin 9 sebagai RST , Pin 10 sebagai SDA (SS) (I2C-Bus Serial Data Line Input/Output), Pin 11 sebagai MOSI (SPI master out), Pin 12 sebagai MISO (SPI master in), Pin 13 sebagai SCK (SPI Serial Clock Input). Mikrokontroler terhubung dengan komputer host melalui koneksi USB (koneksi serial).

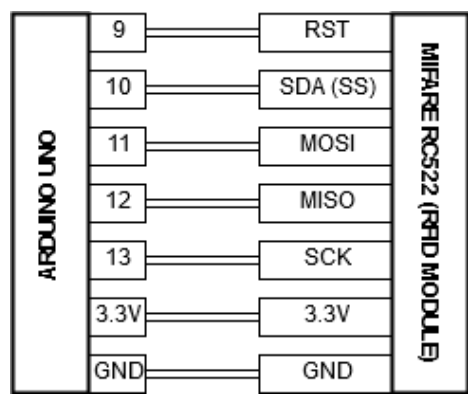

Gambar 5. Wiring diagram.

\subsection{Perancangan Perangkat Lunak (Software)}

\subsubsection{Reader Flowchart}

Gambar 6 menjelaskan mengenai Reader Flowchart. fungsi dari reader flowchart ini adalah bagaimana data dari tag dapat dibaca oleh komputer. Apabila terdeteksi tag baru, maka sistem RFID akan mengambil data dari tag. Jika gagal membaca data pada tag, maka sistem akan menampilkan error dan sistem kembali ke keadaan menunggu tag baru. Jika berhasil mendapatkan data tag, maka sistem akan menampilkan detail data dari tag tersebut. 


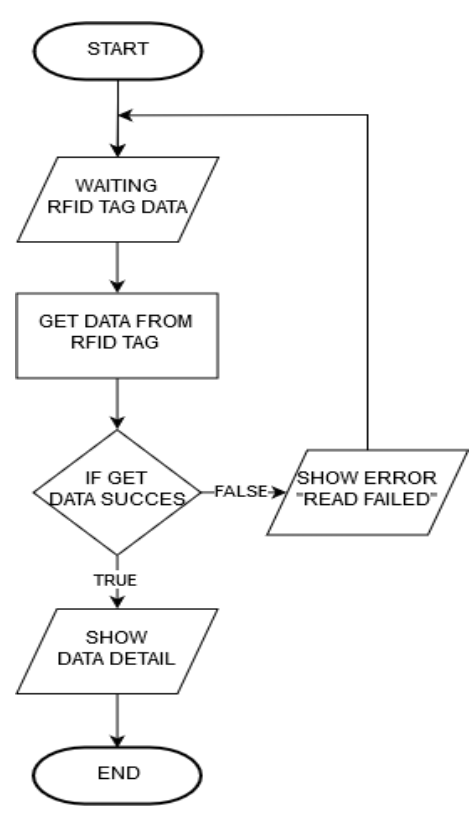

Gambar 6. Reader Flowchart.

\subsubsection{Writer Flowchart}

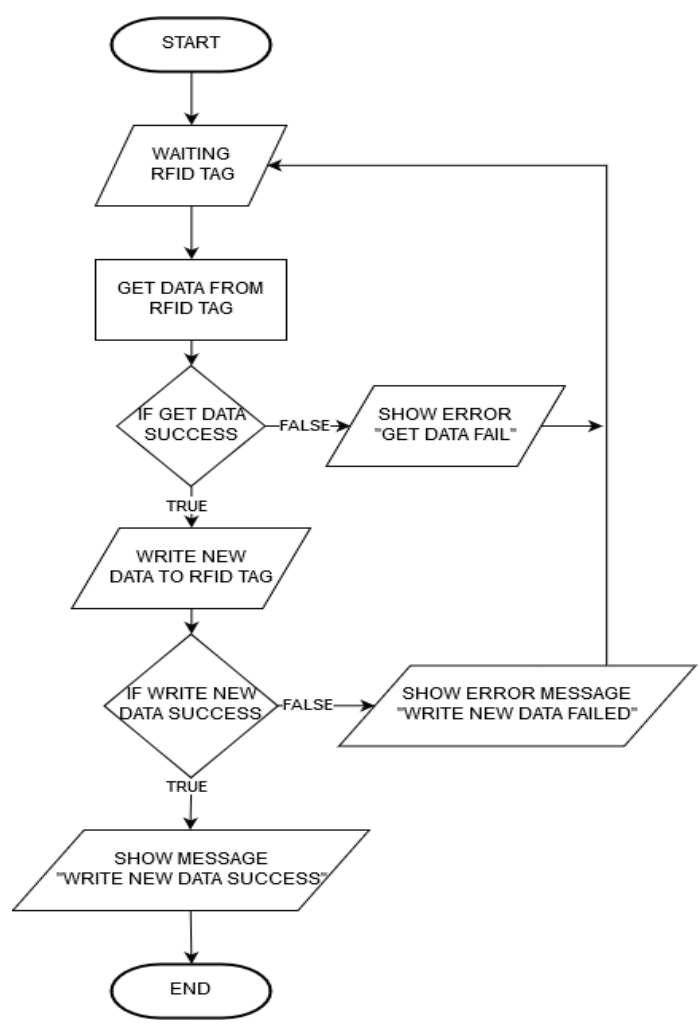

Gambar 7. Writer Flowchart.

Gambar 7 menjelaskan mengenai Writer Flowchart. Fungsi dari writer flowchart ini adalah bagaimana data dari komputer host dapat ditulis kedalam tag. Apabila terdeteksi tag baru, maka sistem RFID akan mengambil data dari tag. Jika gagal membaca data pada tag, maka sistem akan menampilkan error dan sistem kembali ke keadaan menunggu tag baru. Jika berhasil mendapatkan data tag, maka sistem akan memerintahkan user untuk memasukkan data baru yang akan dituliskan ke dalam tag. Jika penulisan data gagal, maka akan menampilkan pesan error dan proses akan kembali ke keadaan menunggu tag baru. Jika penulisan data berhasil, maka sistem akan menampilkan pesan sukses.

Analisis Pembacaan dan Penulisan Data Buku Menggunakan RFID Mifare RC-522 untuk Perpustakaan (Mochamad Reza Adhitama) 


\section{Hasil dan Analisis}

\subsection{Implementasi Sistem}

Realisasi perancangan dari RFID Interogator yang telah dibuat ditunjukkan pada Gambar 8 . Tampilan Serial IDE dari Arduino dapat dilihat pada Gambar 9. Terdapat 2 menu pada sistem RFID yaitu Read dan Write.

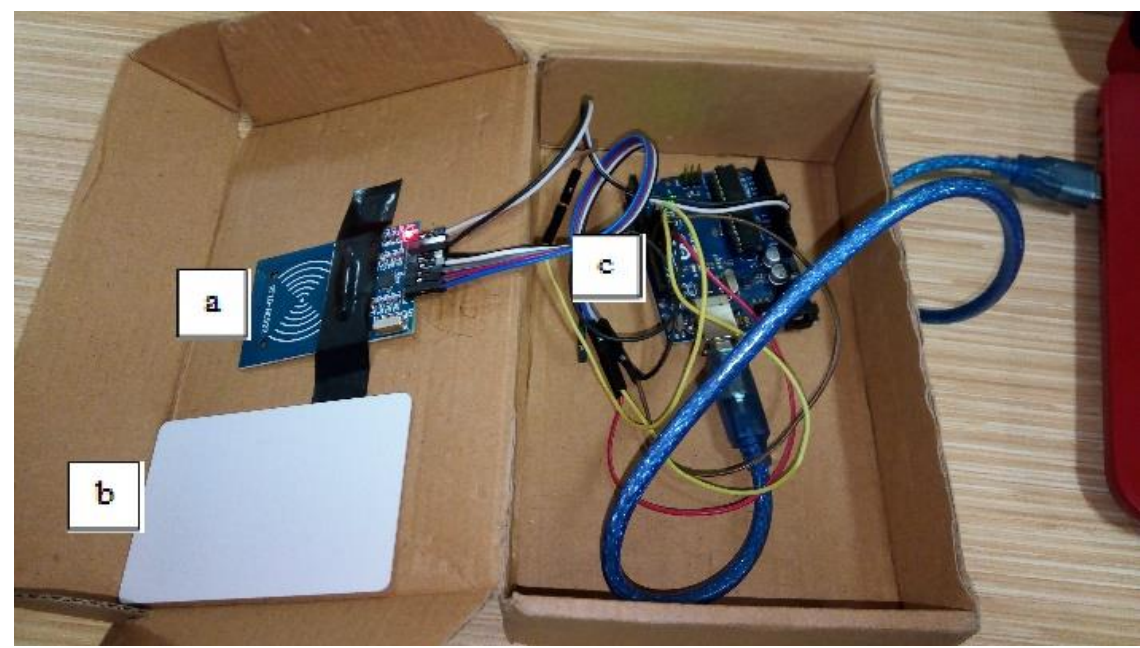

Gambar 8. RFID Interogator.

Penjelasan Gambar 8 : a. Mifare RC522, b. Mifare Classic 1KB, c. Arduino Uno R3.

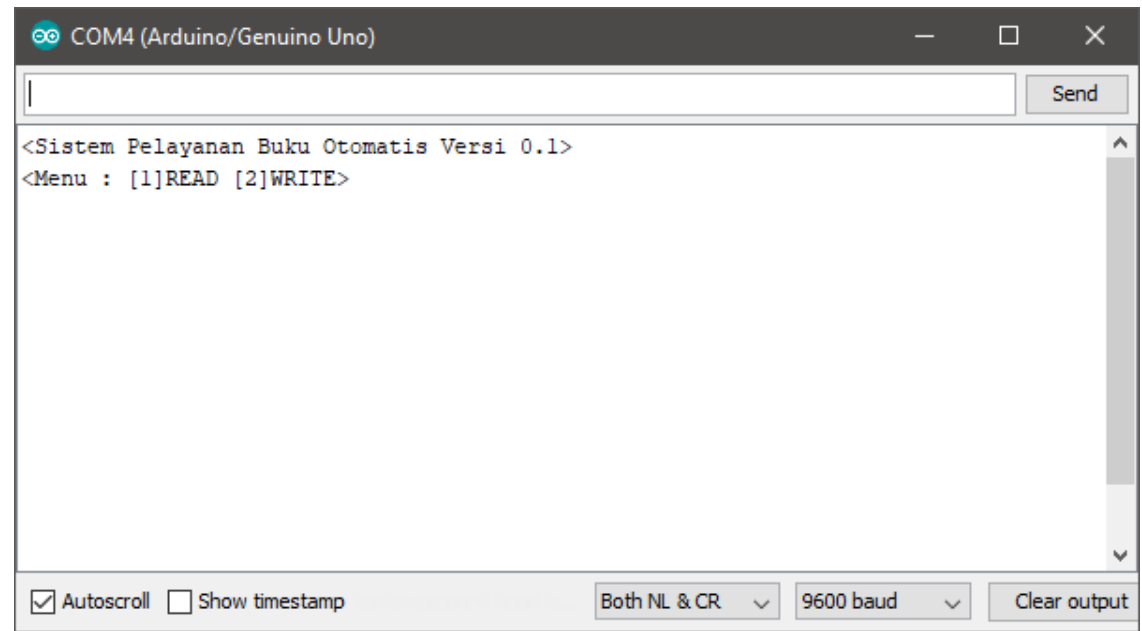

Gambar 9. Tampilan Awal pada Serial IDE.

\subsection{Pengujian Sistem RFID Interogator}

\subsubsection{Pengujian pada Jarak $0 \mathrm{~cm}$}

Pengujian pertama dilakukan dengan kondisi tag diletakkan di atas RFID Interogator dengan jarak $0 \mathrm{~cm}$. Setiap pengujian dilakukan sebanyak $10 \mathrm{kali}$ untuk menguji tingkat akurasi dari RFID Interogator. Gambar 10 merupakan ilustrasi dari pengujian tag dengan posisi vertikal dan horizontal. 

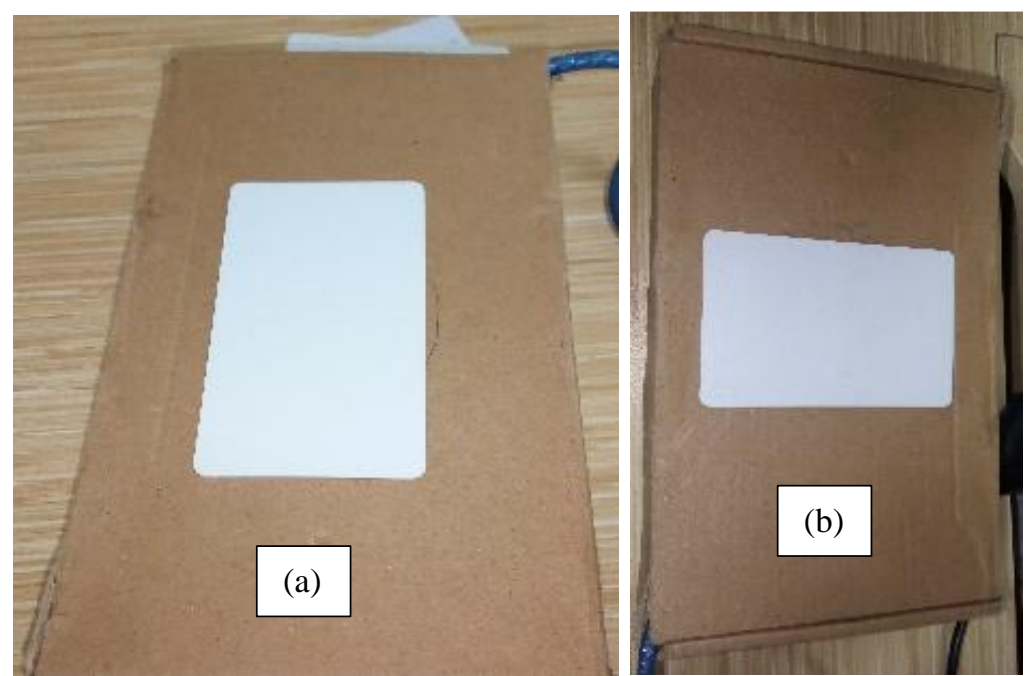

Gambar 10. Pengujian Posisi Tag. a: Pengujian Vertikal, b: Pengujian Horizontal.

Tabel 2. Pengujian jarak $0 \mathrm{~cm}$.

\begin{tabular}{lll}
\hline Pengujian & Posisi & Akurasi \\
\hline Baca & Vertikal & $100 \%$ \\
\hline Baca & Horizontal & $100 \%$ \\
\hline Tulis & Vertikal & $90 \%$ \\
\hline Tulis & Horizontal & $90 \%$ \\
\hline
\end{tabular}

Dapat dilihat pada Tabel 2, bahwa pada pengujian pembacaan didapatkan baik tag dengan posisi vertikal atau horizontal memiliki akurasi mencapai $100 \%$. Proses pembacaan data dapat dilihat seperti pada Gambar 11.

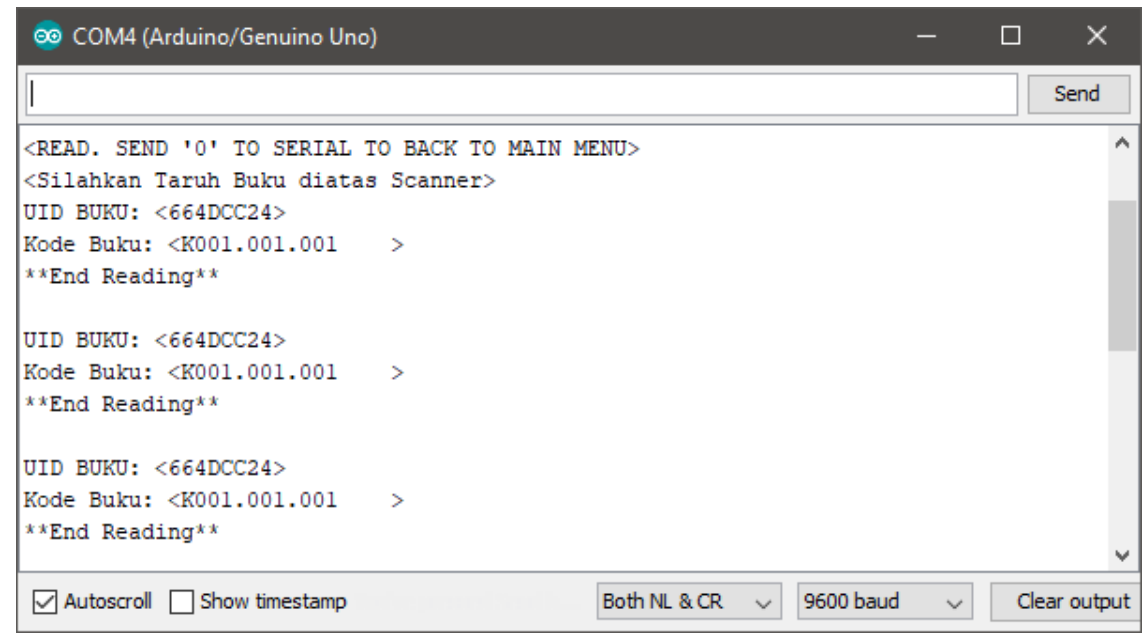

Gambar 11. Pengujian pembacaan data.

Pada pengujian penulisan data, didapatkan bahwa baik tag dengan orientasi vertikal maupun horizontal memiliki tingkat akurasi mencapai 90\% (Tabel 2). Error yang terjadi (lihat Gambar 14) pada proses penulisan data diakibatkan oleh tergesernya tag, sehingga dianggap lost contact. Sehingga perlu mengulang proses penulisan data hingga sukses. Proses penulisan data dapat dilihat seperti pada Gambar 12 dan Gambar 13. 


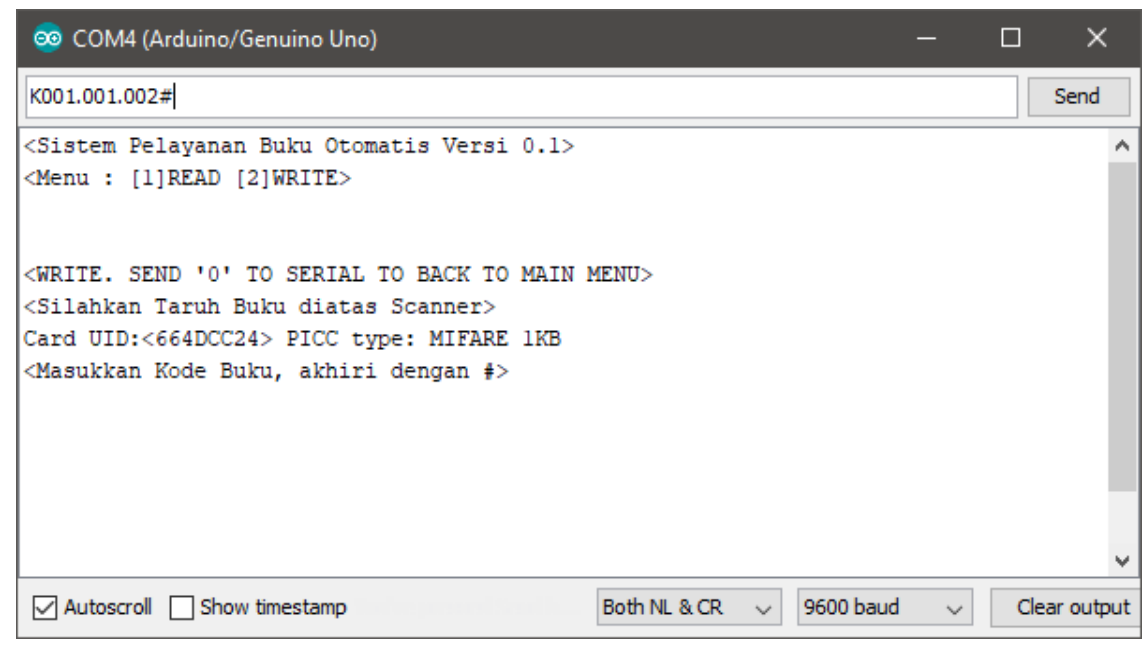

Gambar 12. Proses penulisan data.

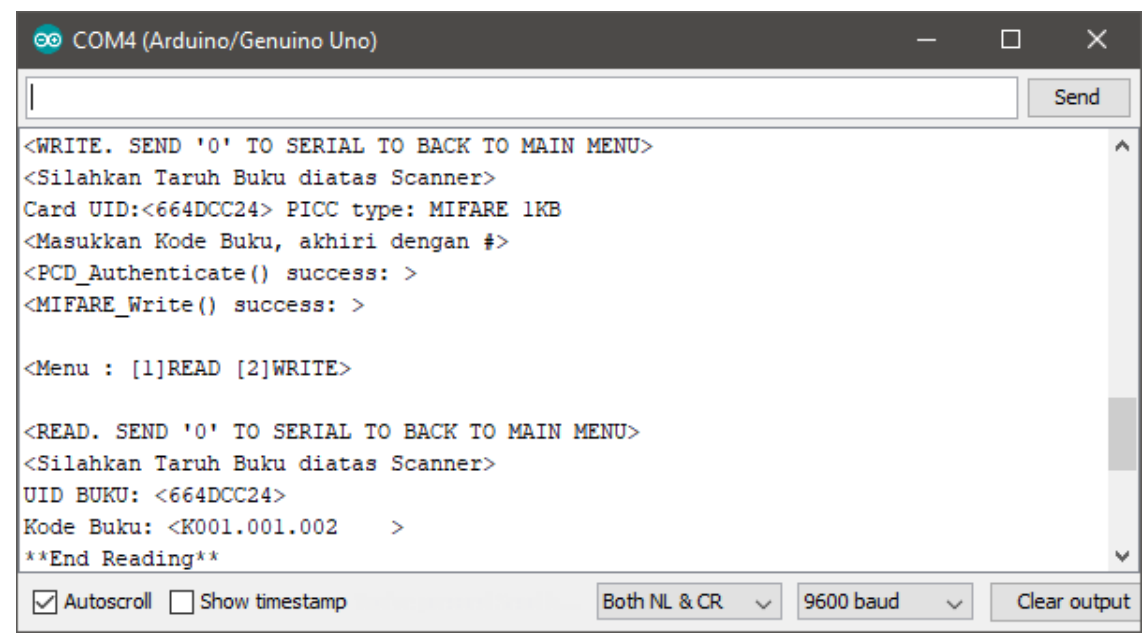

Gambar 13. Penulisan data saat sukses.

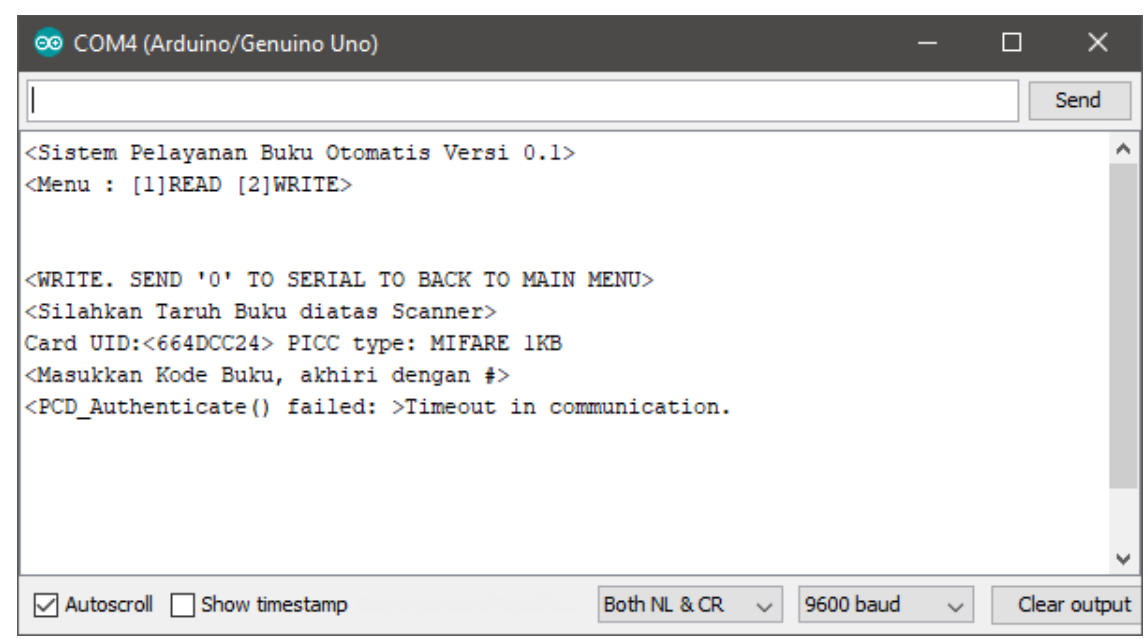

Gambar 14. Error penulisan data.

Pada pengujian pertama didapatkan bahwa posisi tag tidak memiliki pengaruh signifikan terhadap deteksi. Sehingga pada pengujian selanjutnya posisi tag yang digunakan adalah vertikal. 


\subsubsection{Pengujian Error Pembacaan dengan Tag yang Bergerak}

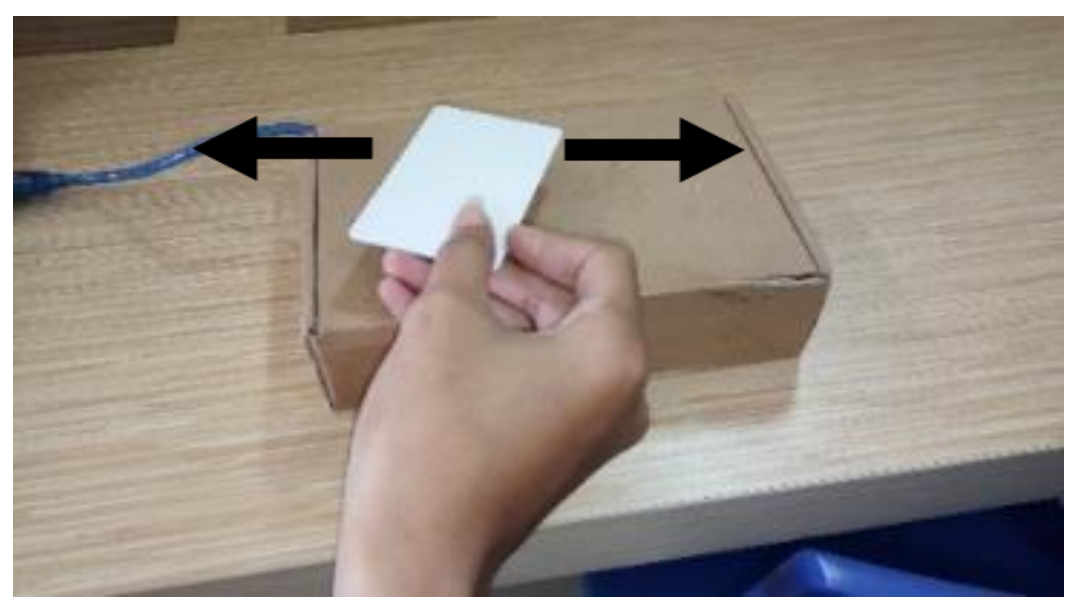

Gambar 15. Tag bergerak.

Pengujian ini dilakukan untuk mencari pesan error yang terjadi saat pembacaan data pada tag (Gambar 15). Didapatkan bahwa error terjadi apabila tag bergerak sangat cepat. Error diakibatkan oleh kegagalan komunikasi antara tag dan RFID Interogator. Error yang terjadi dapat dilihat pada Gambar 16, Gambar 17 dan Gambar 18. Pada error "Reading Failed", membutuhkan Reset RFID Interogator atau Reset Serial Connection agar program dapat berjalan kembali.

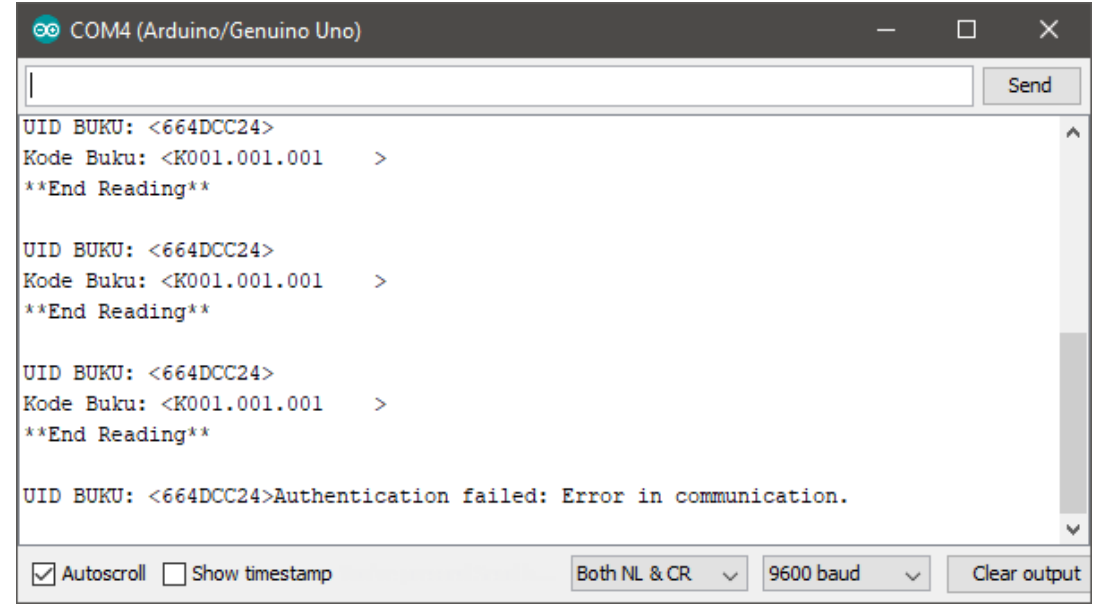

Gambar 16. Authentification failed: Error in communication.

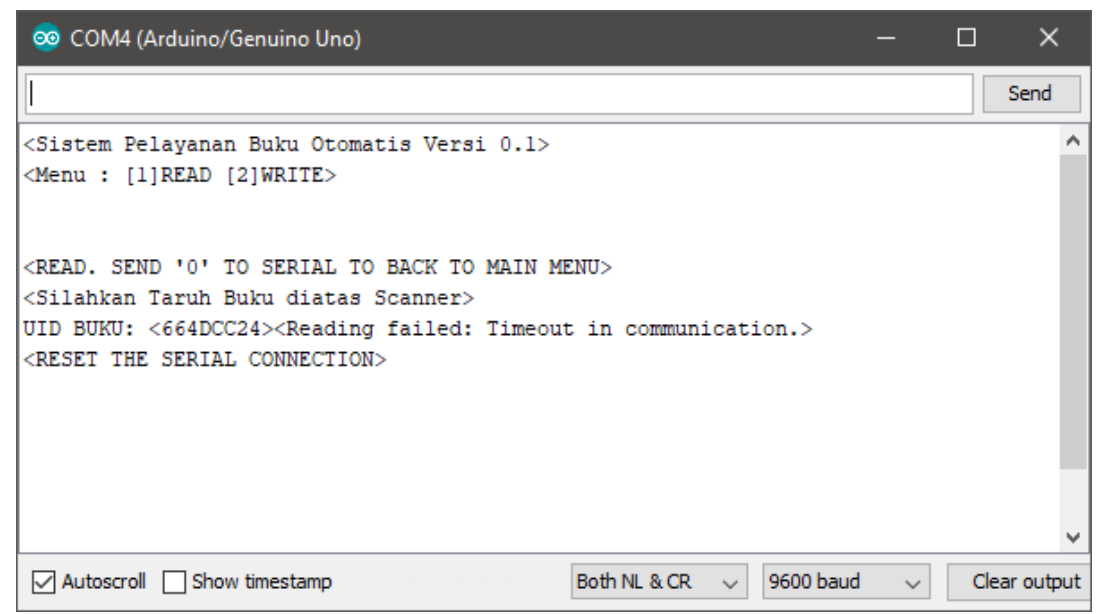

Gambar 17. Reading failed: Timeout in communication.

Analisis Pembacaan dan Penulisan Data Buku Menggunakan RFID Mifare RC-522 untuk Perpustakaan (Mochamad Reza Adhitama) 


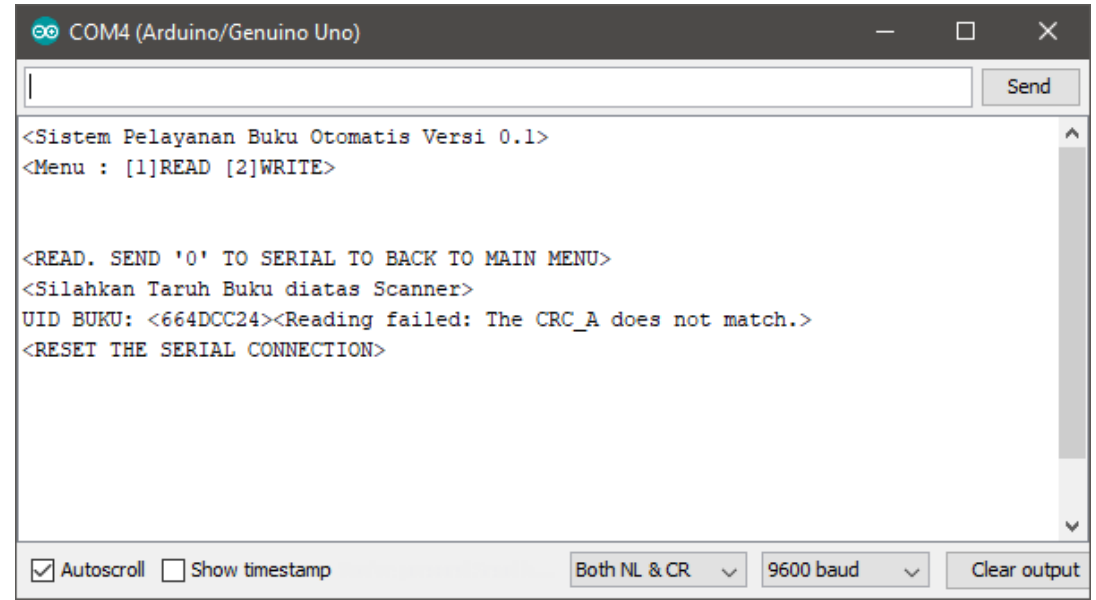

Gambar 18. Reading failed: The CRC A does not match.

\subsubsection{Pengujian dengan Variasi Jarak}

Pengujian ini dilakukan untuk membandingkan akurasi pembacaan dan penulisan data pada tag dengan variasi jarak dimulai dari $1.5 \mathrm{~cm}$ sampai jarak maksimum pembacaan (dengan kenaikan per $1 \mathrm{~cm}$ ). Didapatkan bahwa jarak maksimum dari deteksi tag adalah $\pm 3.5 \mathrm{~cm}$ (Gambar 19). Kemudian dilakukan pengujian sebanyak 10 kali untuk melihat tingkat akurasi, baik pembacaan tag dan penulisan data pada tag.

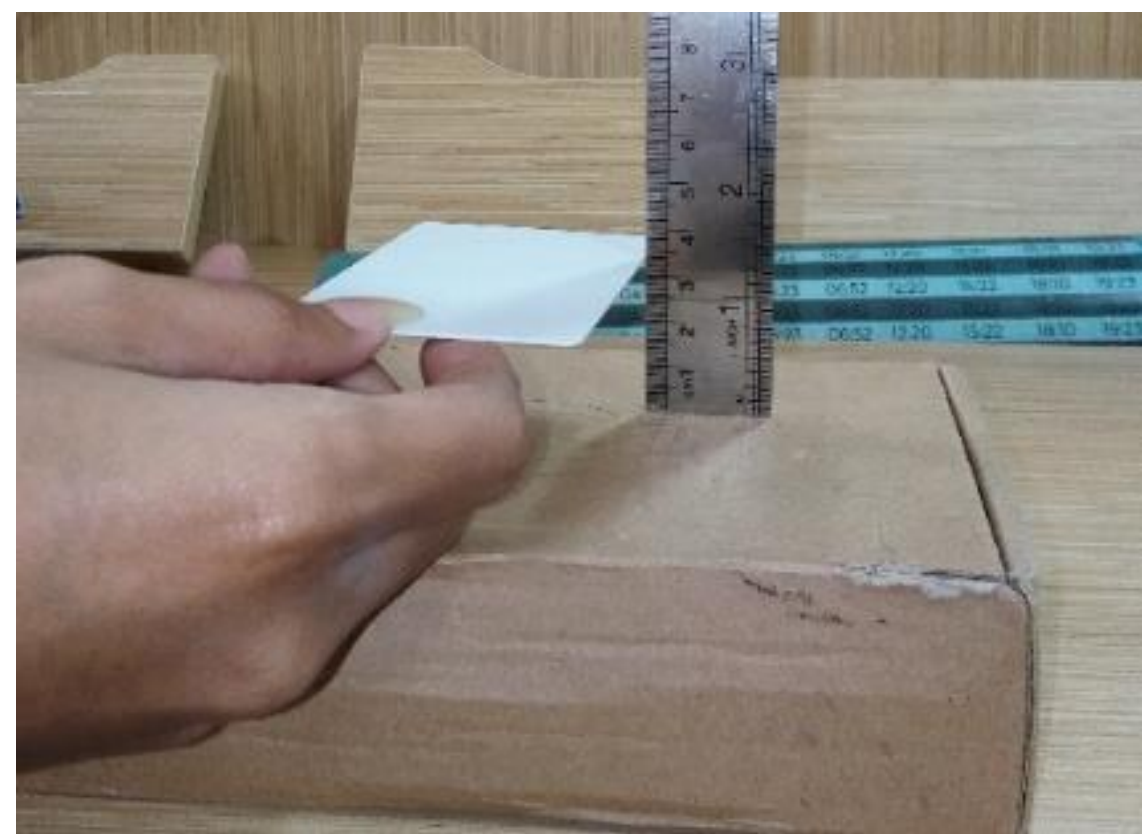

Gambar 19. Jarak maksimum deteksi tag.

Tabel 3. Pengujian jarak $3.5 \mathrm{~cm}$.

\begin{tabular}{ccc}
\hline Pengujian & Jarak & Akurasi \\
\hline Baca & $3.5 \mathrm{~cm}$ & $80 \%$ \\
\hline Baca & $2.5 \mathrm{~cm}$ & $80 \%$ \\
\hline Baca & $1.5 \mathrm{~cm}$ & $100 \%$ \\
\hline Tulis & $3.5 \mathrm{~cm}$ & $0 \%$ \\
\hline Tulis & $2.5 \mathrm{~cm}$ & $100 \%$ \\
\hline Tulis & $1.5 \mathrm{~cm}$ & $80 \%$ \\
\hline
\end{tabular}

Pada Tabel 3 dapat dilihat bahwa tingkat keberhasilan pembacaan pada jarak $3.5 \mathrm{~cm}$ mencapai $80 \%$. Sedangkan pada pengujian penulisan data dengan jarak $3.5 \mathrm{~cm}$, akurasinya $0 \%$. Sehingga disarankan 
untuk melakukan pembacaan atau penulisan data dengan jarak tag dengan RFID interrogator kurang atau sama dengan $2.5 \mathrm{~cm}$.

\subsubsection{Pengujian RFID Tag dengan Buku}

Pengujian ini dilakukan untuk membandingkan akurasi pembacaan dan penulisan data pada tag saat ditempelkan dengan buku (Gambar 20 dan Gambar 21). Pengujian dilakukan sebanyak masing-masing 10 kali per jarak baca. Didapatkan bahwa tidak ada perbedaan signifikan antara sebelum atau sesudah tag ditempelkan dengan buku, dapat dilihat pada Tabel 4.

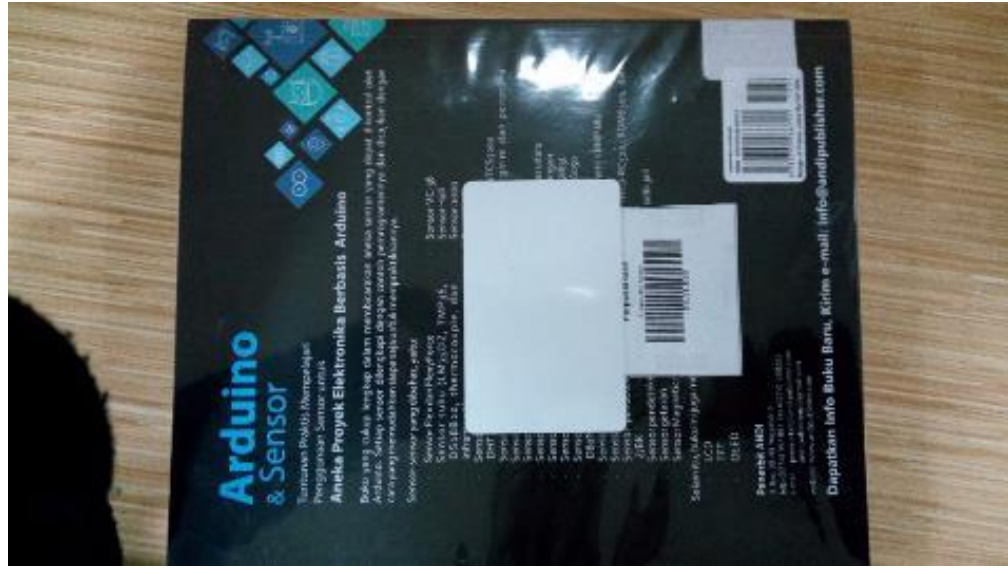

Gambar 20. Tag dengan buku.

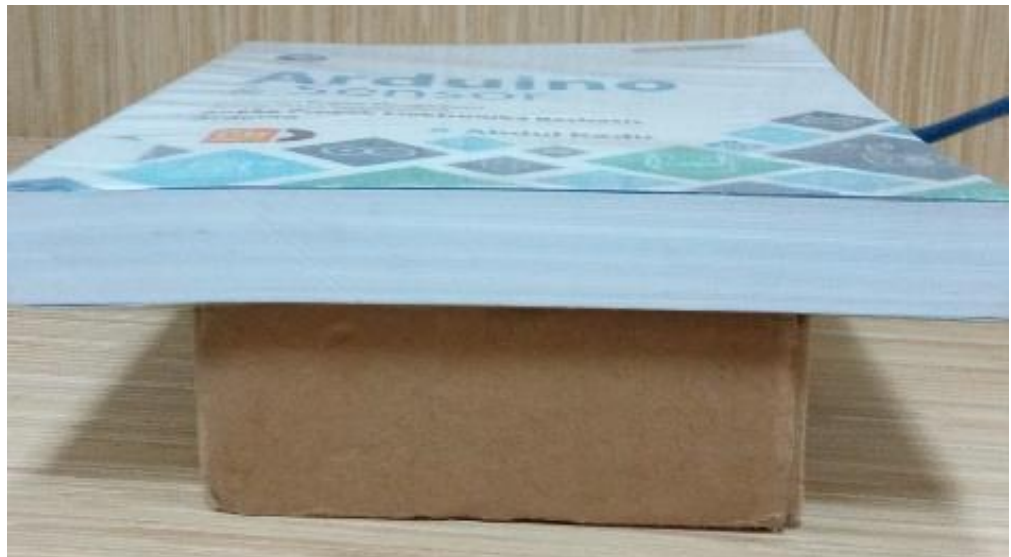

Gambar 21. Pengujian pembacaan dan penulisan data pada Tag dengan buku.

Tabel 4. Perbandingan pengujian tag tanpa buku dan tag di belakang buku.

\begin{tabular}{ccc}
\hline \multicolumn{3}{c}{ Pengujian Tag tanpa Buku } \\
\hline Pengujian & Jarak & Akurasi \\
\hline Baca & $3.5 \mathrm{~cm}$ & $80 \%$ \\
\hline Baca & $2.5 \mathrm{~cm}$ & $80 \%$ \\
\hline Baca & $1.5 \mathrm{~cm}$ & $100 \%$ \\
\hline Tulis & $3.5 \mathrm{~cm}$ & $0 \%$ \\
\hline Tulis & $2.5 \mathrm{~cm}$ & $100 \%$ \\
\hline Tulis & $1.5 \mathrm{~cm}$ & $80 \%$ \\
\hline
\end{tabular}

\begin{tabular}{|c|c|c|}
\hline \multicolumn{3}{|c|}{ Pengujian Tag di Belakang Buku } \\
\hline Pengujian & Jarak & Akurasi \\
\hline Baca & $3.5 \mathrm{~cm}$ & $80 \%$ \\
\hline Baca & $2.5 \mathrm{~cm}$ & $90 \%$ \\
\hline Baca & $1.5 \mathrm{~cm}$ & $100 \%$ \\
\hline Tulis & $3.5 \mathrm{~cm}$ & $0 \%$ \\
\hline Tulis & $2.5 \mathrm{~cm}$ & $90 \%$ \\
\hline Tulis & $1.5 \mathrm{~cm}$ & $90 \%$ \\
\hline
\end{tabular}

\section{Kesimpulan}

Dari penelitian yang dilakukan dapat disimpulkan bahwa :

1. Jumlah memori yang dapat digunakan untuk menyimpan data sebanyak 752 bytes.

2. Data dapat ditulis berulang kali ke dalam RFID Tag.

3. Pada pengujian posisi kartu, didapatkan bahwa posisi tidak memiliki pengaruh terhadap proses pembacaan dan penulisan. 
4. Jarak yang direkomendasikan untuk pembacaan tag adalah $\leq 3.5 \mathrm{~cm}$ dengan tingkat akurasi mencapai $80 \%$ sedangkan untuk rekomendasi jarak penulisan data pada tag adalah $\leq 2.5 \mathrm{~cm}$ dengan tingkat akurasi $90 \%$.

5. Kegagalan pembacaan atau penulisan data pada tag diakibatkan oleh sistem yang kehilangan kontak dengan tag, dan

6. Pengujian saat tag tertempel pada buku tidak memiliki pengaruh signifikan baik dari segi pembacaan maupun penulisan data.

Untuk penelitian selanjutnya, sistem ini akan diterapkan dengan sistem automasi perpustakaan yang sudah ada (misalkan SLiMS [1], [2]).

\section{Daftar Pustaka}

[1] M. Azwar, "Membangun Sistem Otomasi Perpustakaan Dengan Senayan Library Management System (SLiMS)," Khizanah Al-Hikmah, vol. 1, no. 1, pp. 19-33, 2013.

[2] J. K. Cahyono and H. Heriyanto, "Analisis Pemanfaatan Senayan Library Management System (SLiMS) Di Kantor Perpustakaan Dan Arsip Daerah Kota Salatiga," Jurnal Ilmu Perpustakaan, vol. 2, no. 3, pp. 1-10, 2013.

[3] R. Singh, "Use and Importance of Barcode System in Libraries," UNIVERSITY NEWS, vol. 41, no. 08, pp. 5-9, 2003.

[4] K. Finkenzeller, RFID Handbook: Fundamentals and Applications in Contactless Smart Cards, Radio Frequency Identification and Near-Field Communication. Third Edition., Chichester, West Sussex: Wiley, 2010.

[5] M. Adhitama, A. Triwiyatno and B. Setiyono, "Implementasi RFID Untuk Identifikasi Buku Pada Perpustakaan," Transient, vol. 2, no. 1, pp. 24-31, 2013.

[6] I. Sommervile, Sofware Engineering 10th Edition, Harlow: Pearson Education Limited, 2016.

[7] NXP Semiconductors N.V., "MF1S50YYX_V1MIFARE Classic EV1 1K - Mainstream contactless smart card IC for fast and easy solution development Rev. 3.2," 23 Mei 2018. [Online]. Available: https://www.nxp.com/docs/en/data-sheet/MF1S50YYX_V1.pdf . [Accessed 16 April 2019].

[8] NXP Semiconductors N.V., "MFRC522 Standard performance MIFARE and NTAG frontend Rev. 3.9," 27 April 2019. [Online]. Available: https://www.nxp.com/docs/en/data-sheet/MFRC522.pdf. [Accessed 21 March 2019].

[9] Arduino, "Arduino Uno R3," Arduino, 2019. [Online]. Available: https://store.arduino.cc/usa/arduino-uno-rev3 . [Accessed 7 May 2019].

[10] S. J. Sugumar, K. Pachori and T. Chowhan, "Assets Management Device using Embedded Based IoT and RF-ID System for Remote Monitoring," in 7th International Conference, ICIECE., Hyderabad, 2019. 